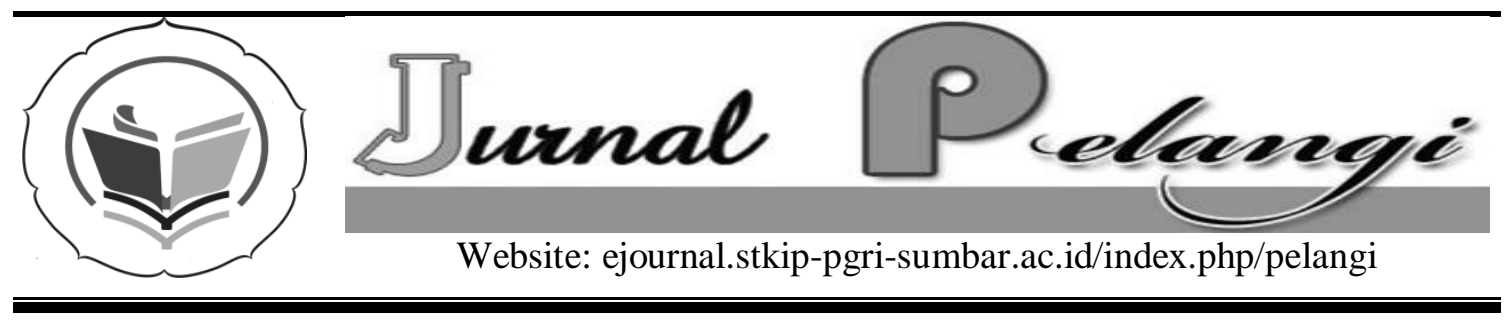

\title{
PENGEMBANGAN LEMBAR KEGIATAN SISWA (LKS) BERBASIS PROBLEM BASED LEARNING (PBL) PADA MATERI POLA BILANGAN
}

\author{
Zulfitri Aima, Siskha Handayani, dan Tri Media Putri \\ STKIP PGRI Sumatera Barat \\ zulfitriaima@gmail.com
}

\section{INFO ARTIKEL}

Diterima:

1 Agustus 2016

Direview:

27 September 2016

Disetujui:

28 Desember 2016

\section{Kata Kunci:}

Lembar Kerja,PBL, Pola Bilangan

\begin{tabular}{l}
\hline Keywords: \\
\hline Worksheet, Problem \\
Based Learning, \\
Number Patterns \\
\\
\hline
\end{tabular}

\begin{abstract}
Abstrak
Penelitian ini dilatarbelakangi oleh bahan ajar yang ada di MAN 1 Padang yang belum dapat membantu siswa dalam menyelesaikan berbagai permasalahan. Oleh karena itu, di kembangkan Lembar Kegiatan Siswa (LKS) berbasis Problem Based Learning (PBL) pada materi Pola Bilangan. yang valid, praktis dan efektif. Prosedur pengembangan yang digunakan adalah model pengembangan ploomp yang terdiri dari 3 fase yaitu tahap investigasi awal, tahap pembuatan prototipe dan assesment phase. Lembar Kegiatan Siswa (LKS) berbasis Problem Based Learning (PBL) terdiri dari 5 tahap. Mengorientasikan siswa pada siswa, mengorganisasikan siswa untuk belajar, membimbing pengalaman individual/ kelompok, menyajikan hasil karya dan mnnganalisis hasil evaluasi. Berdasarkan analisis data dapat disimpulkan bahwa Lembar Kegiatan Siswa (LKS) berada pada kriteria valid dengan ratarata $79 \%$. Hasil analisis angket praktikalitas untuk guru sebesar $100 \%$ dan hasil analisis angket praktikalitas untuk siswa sebesar $87 \%$ dengan kategori sangat praktis. Hasil analisis belajar siswa pada tahap efektif sebesar 84,2 dengan kategori efektif. Keseimpulan penelitian ini menghasilkan Lembar Kegiatan Siswa (LKS) berbasis Problem Based Learning (PBL) yang valid, praktis dan efektif pada materi Pola Bilangan untuk siswa kelas XI IIS MAN 1 Padang.
\end{abstract}

\begin{tabular}{l} 
Abstract \\
The research background showed that there was a need \\
of teaching materials that exist in MAN 1 Padang one \\
field that can not resolve the existing problems. \\
Therefore, a problem based learning student's worksheet \\
on number patterns. The research aimed at developing a \\
valid, practical and effective Problem Based Learning \\
student's worksheet. The development procedure used \\
\hline
\end{tabular}


was Plomp development model consisting 3 phases i.e.preliminary research, prototyping phase, and assessment phase. The worksheet was developed through 5 learning steps of Problem Based Learning. They were student's orientation of students on issues, organize students to learn, experience guiding individuals or groups, develop and present work, analyze and evaluate the poblem solving process. Based on the data analysis, it can be concluded that the developed student's worksheet is on valid criteria in which the mean is $79 \%$. The result from teacher's practicality questionnaire is $100 \%$ and student's practicality questionnaire is $87 \%$ in a very practical category. The percentage of student's of field test criteria is $84,2 \%$ in an effective category. It can finally be concluded that the research produces a valid, practical, and effective problem based learning student's worksheet on number patterns material at XI IIS class MAN 1 Padang.

\section{PENDAHULUAN}

Matematika merupakan salah satu bidang studi yang ikut berperan penting dalam menunjang ilmu pengetahuan, karena matematika dapat mengembangkan kemampuan berpikir logis, kritis, dan sistematis. Berdasarkan observasi yang telah dilakukan di MAN 1 Padang pada tanggal 26 februari sampai dengan 29 februari 2016, diperoleh informasi bahwa sekolah tersebut adalah salah satu sekolah menengah atas di kota Padang yang melaksanakan kurikulum 2013 pada tahun ajaran 2016/2017 dalam pembelajaran. Dalam proses pembelajaran terlihat guru telah berusaha membuat proses pembelajaran secara aktif, seperti bertanya dengan siswa tentang materi yang belum dipahami namun siswa hanya diam seolah siswa telah mengerti dengan materi yang sedang dipelajari dan pada saat guru memberikan soal latihan, siswa terlihat kesulitan dalam menjawabnya. Bahan ajar yang digunakan siswa berupa buku teks, siswa tidak menggunakan bahan ajar lainnya selama pembelajaran.
Buku teks yang digunakan dalam pembelajaran juga belum memberikan kesempatan kepada siswa untuk menyelesaikan permasalahan.

Dengan adanya permasalahan tersebut perlu dilakukan upaya untuk membantu siswa dalam proses pembelajaran. Salah satu caranya yaitu melengkapi buku pegangan yang dapat mengarahkan pola pikir sekaligus dapat menciptakan kemandirian siswa dalam belajar dan menemukan pengetahuan. Dalam hal ini, Lembar Kegiatan Siswa (LKS) berperan penting untuk mengarahkan pola pikir mereka dalam menemukan pengetahuan baru. Peran guru sebagai fasilitator pun dapat dimaksimalkan, karena siswa akan membangun pengetahuannya secara mandiri dan terarah.

Mengembangkan LKS sangatlah penting dengan menggunakan LKS diharapkan pembelajaran lebih terarah dan dapat membantu siswa mengimplementasikan pengetahuan yang diperolehnya dalam kehidupan sehari-hari. Ada banyak cara yang dapat dilakukan untuk mengembangkan LKS 
menjadi sedemikian rupa. Salah satunya yaitu dengan menerapkan karakteristik pembelajaran berbasis Problem Based Learning dalam penyajian materi LKS. Dengan menerapkan pembelajaran Problem Based Learning diharapkan siswa dapat mengembangkan pemikiran kritis dan keterampilan kreatif, meningkatkan kemampuan memecahkan masalah, meningkatkan motivasi, membantunya belajar untuk mentransfer pengetahuan untuk situasi baru.

Berdasarkan latar belakang yang telah diuraikan diatas, maka dilakukan penelitian dengan judul "Pengembangan Lembar Kegiatan Siswa (LKS) Berbasis Problem Based Learning (PBL) Pada Materi Pola Bilangan untuk Siswa Kelas XI IIS MAN 1 Padang". Berdasarkan rumusan masalah yang telah dikemukakan, tujuan penelitian ini adalah menghasilkan Lembar Kegiatan Siswa (LKS) berbasis Problem Based Learning (PBL) yang valid, praktis dan efektif pada materi pola bilangan untuk siswa kelas XI IIS MAN 1 Padang.

Prastowo (2011: mengemukakan "Lembar Kegiatan Siswa (LKS) adalah suatu bahan ajar yang berisi materi, ringkasan dan petunjuk-petunjuk pelaksanaan tugas yang harus diselesaikan siswa yang mengacu pada kompetensi dasar yang harus dicapai". Lembar Kegiatan Siswa yang dikembangkan adalah Lembar Kegiatan Siswa (LKS) berbasis Problem Based Learning (PBL). Arends (1997) dalam Suprihatiningrum (2013: 215) "Problem Based Learning (PBL) merupakan suatu pendekatan pembelajaran, yang mana siswa mengerjakan permasalahan yang otentik dengan maksud untuk menyusun pengetahuan mereka sendiri, mengembangkan inkuiri, dan keterampilan berpikir lebih tinggi, mengembangkan kemandirian dan percaya diri.
LKS berbasis Problem Based Learning (PBL) diharapkan siswa dapat mengembangkan pemikiran kritis dan keterampilan kreatif, meningkatkan kemampuan memecahkan masalah, meningkatkan motivasi, membantunya belajar untuk mentransfer pengetahuan untuk situasi baru. Ini dapat membatu guru dalam proses pembelajaran. LKS ini akan memotivasi dan membuat siswa ingin membaca dan mempelajarinya.

Penelitian yang relevan dengan penelitian yang dilakukan adalah penelitian yang dilakukan oleh Bety Herlinda (2014) dengan judul "Pengembangan Lembar Kegiatan Siswa (LKS) Berbasis Problem Based Learning (PBL) Pada Materi Pecahan Terhadap Pembelajaran Matematika Siswa Kelas VII SMPN 32 Padang“. Perbedaan penelitian ini dengan penelitian sebelumnya adalah pada penelitian ini menggunakan model pengembangan Instructional Development Institude (IDI) yang terdiri dari tahap define, develop dan evaluate. LKS pada penelitian ini dikembangkan sampai pada tahap praktikalitas.

\section{METODE PENELITIAN}

Jenis penelitian yang dilakukan adalah penelitian dan pengembangan (Research and Development/R\&D). Model pengembangan dalam penelitian ini mengikuti model umum desain penelitian menurut Plomp (2013: 19) yang terdiri atas 3 fase yaitu preliminary research, prototyping phase, dan assessment phase.

Pada tahap Preliminary research yang dilakukan adalah wawancara dengan guru matematika serta siswa, analisis silabus, analisis buku teks, analisis literatur dan analisis karakteristik siswa. Tahap prototyping phase yang dilakukan adalah merancang sistematika dan stuktur LKS, pengembangan prototype dilakukan 
evaluasi diri, tinjauan ahli, evaluasi satusatu dan evaluasi kelompok Kecil. Tahap Assesment Phase yang dilakukan adalah uji coba prototipe LKS terhadap siswa kelas XI IIS MAN 1 Padang. Evaluasi dilakukan pada akhir pembelajaran (Evaluasi Mandiri). Hasil evaluasi digunakan untuk merevisi draft LKS. Uji coba dan evaluasi yang dilakukan adalah uji kelompok besar terhadap satu kelas XI IIS MAN 1 Padang untuk melihat praktikalitas dan efektifitas prototipe.

Instrumen yang digunakan dalam penelitian ini adalah pedoman evaluasi diri, lembar validasi, angket praktikalitas, pedoman wawancara, dan hasil belajar. Lembar validasi digunakan untuk memvalidasi produk yang dilakukan oleh validator. Validator dalam penelitian ini adalah dua orang dosen Program Studi Pendidikan Matematika STKIP PGRI Sumatera Barat. Angket dan pedoman wawancara digunakan untuk melakukan praktikalitas produk. Praktikalitas produk bertujuan untuk melihat keterpakaian produk yang telah disusun, dengan melakukan ujicoba produk secara terbatas pada enam siswa kelas XII IPS dan satu guru Matematika MAN 1 Padang. Tes akhir digunakan untuk melihat hasil belajar siswa guna mengetahui efektivitas LKS.

Hasil validasi dari validator terhadap seluruh aspek yang dinilai, disajikan dalam bentuk tabel. Skor dari masing-masing validator dapat dihitung dengan menggunakan rumus:

$$
N V=\frac{s}{S M} \times 100 \%
$$

dengan

$N V=$ Nilai akhir validasi dari masingmasing validator

$S \quad=$ Skor yang diperoleh

$S M=$ Skor maksimum
Tabel 1. Kriteria Validasi

\begin{tabular}{ll}
\hline \multicolumn{1}{c}{ Persentase (\%) } & \multicolumn{1}{c}{ Kriteria } \\
\hline $25 \leq \bar{x} \leq 40$ & Sangat Tidak Valid \\
$40<\bar{x} \leq 55$ & Tidak Valid \\
$55<\bar{x} \leq 70$ & Cukup Valid \\
$70<\bar{x} \leq 85$ & Valid \\
$85<\bar{x} \leq 100$ & Sangat Valid \\
\hline
\end{tabular}

Analisis data praktikalitas dilakukan dengan memberikan angket dan wawancara kepada enam orang siswa dan satu orang guru matematika. Data angket diperoleh dengan cara menghitung skor siswa dan guru yang menjawab masing-masing item sebagaimana terdapat dalam angket. Data uji praktikalitas LKS dianalisis dengan menghitung persentase menggunakan rumus :

$$
N A=\frac{\text { jumlah semua skor }}{\text { skor maksimum }} \times 100 \%
$$

Tabel 2. Kriteria Praktikalitas

\begin{tabular}{ll}
\hline Persentase (\%) & \multicolumn{1}{c}{ Kriteria } \\
\hline $25 \leq \bar{x} \leq 40$ & Sangat Tidak Praktis \\
$40<\bar{x} \leq 55$ & Tidak Praktis \\
$55<\bar{x} \leq 70$ & Cukup Praktis \\
$70<\bar{x} \leq 85$ & Praktis \\
$85<\bar{x} \leq 100$ & Sangat Praktis \\
\hline
\end{tabular}

Tes hasil belajar dianalisis dengan meggunakan perhitungan persentase siswa yang memenuhi kriteria ketuntasan minimal (KKM). Untuk pengembangan LKS ini dikatakan efektif jika dari $75 \%$ siswa mendapat nilai $\geq$ KKM, Harjanto (2010:285)

Hasil wawancara dengan siswa dianalisis dengan menggunakan analisis kualitatif. Menurut Miles dan Huberman dalam rohidi (199: 16) Analisis kualitatif menggunakan kata-kata yang disusun ke dalam bentuk teks yang diperluas atau berupa kesimpulan. Analisis kualitatif 
terdiri dari tiga alur kegiatan yang terjadi secara bersamaan yaitu reduksi data, penyajian data dan penarikan kesimpulan/verifikasi.

\section{HASIL DAN PEMBAHASAN}

Penelitian pada pengembangan ini dilakukan tiga fase yaitu preliminary research, prototyping phase dan assesment phase. Metode evaluasi formatif yang dilakukan diawali dengan evaluasi diri terhadap produk yang dibuat. Evaluasi diri dilakukan dengan cara mengevaluasi produk yang telah dibuat sesuai dengan pedoman evaluasi diri. Setelah itu dilakukan tinjauan ahli dari masing-masing aspek pengembangan dengan cara diskusi dengan pakar. Tinjauan ahli dilakukan untuk memperoleh produk yang valid, setelah produk dinyatakan valid oleh validator dilakukan uji lapangan terhadap siswa yang telah mempelajari materi pola bilangan dengan evaluasi satu-satu dan kelompok kecil.

Berdasarkan produk yang dirancang diperoleh hasil validasi LKS menurut ahli matematika. Hasil validasi LKS berbasis Problem Based Learning secara keseluruhan dikategorikan valid dengan nilai akhir $79 \%$, sedangkan hasil analisis angket praktikalitas guru sebesar 100\% dan angket praktikalitas siswa sebesar $87 \%$ dengan kategori masing-masing sangat praktis. Hasil wawancara dengan guru dan siswa juga menunjukkan LKS yang sangat praktis. Hasil analisis data efektivitas dengan melihat persentase hasil belajar siswa adalah $84,2 \%$ dengan kategori efektif sehingga LKS berbasis
Problem Based Learning dapat dikatakan efektif. Hal ini menunjukkan bahwa LKS berbasis Problem Based Learning valid, praktis, dan efektif.

\section{PENUTUP}

Berdasarkan hasil penelitian dan hasil analisis data yang dilakukan dapat disimpulkan bahwa penelitian menghasilkan LKS berbasis Problem Based Learning pada materi Pola Bilangan untuk siswa kelas XI IIS MAN 1 Padang yang valid, praktis, dan efektif.

\section{UCAPAN TERIMA KASIH}

Terbitnya tulisan ini tidak terlepas dari bantuan berbagai pihak, untuk itu penulis ucapkan terima kasih kepada UP3M STKIP PGRI Sumatera Barat sebagai penyandang dana dan pengelola jurnal Pelangi yang telah memberikan saran dan revisi dalam penulisan artikel ini.

\section{DAFTAR PUSTAKA}

Prastowo, Andi. 2011. Panduan Kreatif Membuat Bahan Ajar Inovatif. Yogyakarta: Diva Press.

Riduwan. (2012). Belajar Mudah Penelitian Untuk Guru, Karyawan Dan Penulis Pemula. Bandung: Alfabeta.

Suprihatiningrum, jamil. 2013. Strategi Pembelajaran:teori dan aplikasi. Jogjakarta:Ar-Ruzz Media. 